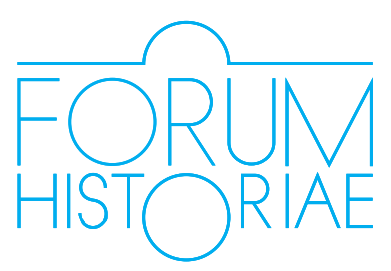

\title{
Stanislav Kostlivý a Konštantín Čársky - elity slovenskej chirurgie*
}

\author{
Anna Falisová - Vojtech Ozorovský
}

\begin{abstract}
FALISOVÁ Anna - OZOROVSKÝ Vojtech: Stanislav Kostlivý and Konštantín Čársky - the Elite of Slovak Surgery.

Following the dissolution of Austria-Hungary and the establishment of Czechoslovakia, Slovak society was struggling from a severe lack of professional elites. A considerable portion of civil servants, academics and pedagogues rejected the new regime and left Slovakia. By examining the cases of two significant figures of medical science (surgery), S. Kostlivý and K. Čársky, this study introduces some key difficulties affecting the establishment of this discipline during inter-war Czechoslovakia. S. Kostlivý was among the founders of Slovak surgery, K. Čársky was a member of the first generation of Slovak surgeons. Political censorship and a profound lack of professionals enabled the rapid career growth of S. Kostlivý at the time Czechoslovakia was founded. K. Čársky experienced similar conditions at the beginning of wartime Slovak Republic as the change of regime in 1938 forced the completion of activities for a majority of Czech intellectuals in Slovakia. As the career of S. Kostlivý shows, neither great competence nor strong social capital within the medical community was sufficient enough to withstand the politically and ideologically motivated purges. However, after a short time, the founding generation of Czech doctors and pedagogues managed to create a solid collection of medical specialists who mitigated, to a certain extent, the effects of personnel disruption due to regime changes.
\end{abstract}

Keywords: surgery, Czechoslovak Republic, Stanislav Kostlivý, Konštantín Čársky, Comenius University, health education

\section{Stanislav Kostlivý - cesta k zvolenej profesii}

tanislav Kostlivý sa narodil 30. októbra 1877. Bol jediným diet’at’om ministerského radcu a zástupcu riaditel'a Ríšskeho meteorologického ústavu vo Viedni. Jeho rodičia pochádzali z Česka a otvorene sa hlásili k českej národnosti. V centre monarchie žila koncom 19. storočia početná česká menšina, s ktorou udržiavala rodina Kostlivých živé kontakty. ${ }^{1}$ Kostlivý sa po maturite rozhodol pre štúdium medicíny na Lekárskej fakulte vo Viedni. Počas vysokoškolského štúdia nadviazal bohaté kontakty s českými a slovenskými študentmi a navštevoval Slovanskú besedu. Po promócii v roku 1902 sa usiloval „zakotvit““ vo Viedni. Prednostom I. chirurgickej kliniky bol profesor Eduard Albert, vynikajúci chirurg českého pôvodu, ktorý bol priatel'om rodiny Kostlivých a mladého absolventa medicíny podporoval v jeho snažení. Bol preňho vel'kým vzorom. Kostlivý krátko pracoval na chirurgicko-gynekologickom oddelení doc. Dr. Friedlendera, potom rok a pol na chirurgickom oddelení profesora Franka vo Všeobecnej nemocnici, kde publikoval aj svoju prvú vedeckú prácu. ${ }^{2}$ Ako národne uvedomelý Čech mal

\footnotetext{
* Táto práca je výsledkom riešenia grantových úloh APVV-14-0644 Kontinuity a diskontinuity politických a spoločenských elít na Slovensku v 19. a 20. storočí a grantovej úlohy VEGA 2/0100/16 Zdravotníctvo na Slovensku v rokoch 1948 - 1966.

1 TIBENSKÝ, Ján - PÖSS, Ondrej a kol. Priekopníci vedy a techniky na Slovensku 3. Bratislava : AEP 1999, s. 90.

2 Archív Univerzity Komenského (AUK), fond Rektorát Univerzity Komenského (RUK), personálne oddelenie pedagogickí zamestnanci, osobný spis Stanislav Kostlivý, k. 95; KOTHAJ, Peter a kol. Momenty z dejín slovenskej chirurgie. Profesor Kostlivý, jeho žiaci a nasledovníci. Prievidza : Patria, 1999, s. 39.
} 
však problémy kariérne sa natrvalo presadit' vo Viedni. ${ }^{3}$ Počas tohto obdobia sa aj oženil s Bohumilou, dcérou ministra školstva A. Rezka, vnučkou básnika Karla Jaromíra Erbena. Zrejme na odporúčanie profesora Alberta odišiel do Prahy, kde v rokoch 1905 - 1909 pôsobil ako asistent na I. chirurgickej klinike u profesora Otakara Kukulu. Na novom pôsobisku už v začiatkoch vynikal nad priemer. Na klinike získal široké vzdelanie, bol vynikajúci operatér. Popri brušnej chirurgii, ktorá bola jeho prioritou, technicky bravúrne zvládol aj oblast' urológie, ušného, nosného lekárstva, gynekológie a zoznámil sa so zámermi vznikajúcej ortopédie. ${ }^{4}$ Získal odbornú špecializáciu a stal sa jedným z popredných reprezentantov Kukulovej chirurgickej školy. V roku 1909 prijal ponuku na miesto primára - chirurga vo Všeobecnej verejnej nemocnici v Třebíči na Morave. Práca ho napíňala a onedlho sa stal aj riaditelom nemocnice. V Třebíči sa venoval praktickej chirurgii a všetkým jej príbuzným odborom. Všestrannost', ktorú získal na tomto pracovisku v oblasti chirurgie, neskôr jeho žiakov vychovávaných v úzkej špecializácii prekvapila a často zahanbovala. V roku 1912 sa na Českom vysokom učení technickom v Brne habilitoval na docenta chirurgie a zároveň bol vymenovaný aj prezidentom lekárskej komory v Markrabství moravském. Prvá svetová vojna Kostlivého čiastočne pripútala k Slovensku, ked’že dlhší čas pôsobil v oblasti Karpát. Zúčastnil sa expedície českých chirurgov, kde získal cenné skúsenosti pri ošetrovaní vojnových poranení. ${ }^{5}$

\section{S. Kostlivý - osobnost' a jeho prínos pre zdravotníctvo na Slovensku}

Vznik Československej republiky znamenal radikálny medzník v živote S. Kostlivého. Z rúk prezidenta republiky T. G. Masaryka prevzal 31. júla 1919 profesorský dekrét a ako riadny profesor chirurgie spoločne s d’alšími českými kolegami pricestoval do Bratislavy. Tu sa začala nová etapa jeho života. Ministerstvo školstva a národnej osvety (MŠNO) v Prahe vyzvalo Kostlivého, aby sa predstavil prezídiu MŠNO, zložil predpísanú služobnú prísahu a ujal sa svojho úradu. Jeho povinnosti špecifikovalo: „Spolupůsobiti při organisaci a budovaní lékařské fakulty v Bratislavě, zejména pak zaříditi a vésti chirurgickou kliniku jakož i obor, pro nějž Jste jmenován, podle předpisưv té doby platných řádně zastupovati; obzvláště pak máte závazek, abyste konal z oboru svého přednášky rozsahem odpovídajícím vyučovací potrebě university v Bratislavě." Zároveň ho informovali, aby čo najskôr podnikol potrebné kroky na rozviazanie pracovného pomeru a bol uvol'nený z funkcie primára nemocnice v Třebíči. Všetky výdavky spojené s prest'ahovaním hradilo Generálne finančné riaditel'stvo v Bratislave podla noriem platných pre Slovensko. ${ }^{7}$ V roku 1919 sa celá rodina prest’ahovala do Bratislavy. Na Slovensko prišiel Kostlivý

3 ČÁRSKY, Konštantín. Osobnost’ a vedecké dielo prof. Dr. Stanislava Kostlivého. In Bratislavské lekárske listy (d’alej len $B L L$ ), 1947, roč. 27, príloha, s. 638.

4 ČHECH, Oldřich. Historie československé, české a slovenské ortopedie. (Mimoriadne číslo Acta chirurgiae orthopaedicae et traumatologiae Čechoslovaca), Galen : Praha 2009, s. 24.

5 ČHECH 2009, s. 24-25.

6 AUK, f. RUK, personálne oddelenie - pedagogickí zamestnanci, osobný spis Stanislav Kostlivý, k. 95; MŠNO v Prahe. Dňa 6. 8. 1919.

7 AUK, f. RUK, personálne oddelenie - pedagogickí zamestnanci, osobný spis Stanislav Kostlivý, k. 95; MŠNO v Prahe. Dňa 6. 8. 1919. 
v správnom čase a na správne miesto. ${ }^{8}$ Dňa 20. augusta 1919 prevzal vedenie Chirurgickej kliniky Lekárskej fakulty UK. ${ }^{9}$ Po skončení vojny mad’arská chirurgická elita opustila Slovensko a tým, že si profesor Kostlivý priviedol niektorých asistentov z Česka, podarilo sa mu preklenút' t’ažkosti spojené s nedostatkom odborného personálu. Pod jeho vedením dosiahlo pracovisko už v prvých rokoch svojej existencie európsku úroveň. ${ }^{10}$ Podl'a spomienok jeho žiakov bol prednostom, v ktorého osobe sa spojili dve vynikajúce vlastnosti: „[...] dobroprajnost' všestranne vzdelaného človeka s vysokou odbornou kvalifikáciou a manuálnou zručnostou chirurga."11 Vyznačoval sa brilantnou operačnou technikou a jeho žiak J. Kňazovický, ktorý prevzal vedenie chirurgického oddelenia v Košiciach, o profesorovi Kostlivom napísal: „Operoval zručne, preparoval anatomicky, jeho technika bola do posledných rokov brilantná, šetriaca vždy živú tkaň a živú buňku. [...] Ako lekár vynikal svojím všeobecným medicínskym vzdelaním. Nebol proporcionálnym, díval sa vždy na celého človeka. [...] Voči chorému bol samá humanita. Hlboké sociálne cítenie nenosil na perách, ale mal ho vždy v srdci."'22 Bratislavská chirurgická klinika bola jediným kompletne vybaveným chirurgickým ústavom na Slovensku. Profesor Kostlivý neustále skvalitňoval prácu kliniky, zvyšoval počet a spektrum operačných výkonov a vyučoval nových žiakov. ${ }^{13} 0$ rozsahu odbornej činnosti pracoviska svedčí aj samotný fakt, že počet pacientov, ktorí tu vyhl'adávali odbornú pomoc, sa neustále zvyšoval. ${ }^{14}$

Vo vedeckovýskumnej práci a klinickej praxi sa profesor Kostlivý zaoberal chirurgiou endokrinných žliaz, špeciálne strumou, problémami abdominálnej chirurgie, tuberkulózou plúc, tiež urológiou, traumatológiou a chirurgickou röntgenológiou. Medzi prvými v republike i v Európe zaviedol na klinike Orrovú metódu. Uverejnil vyše 70 štúdií a článkov v domácich a zahraničných odborných periodikách. Bol priekopníkom resekcie duodenálnych vredov a patril aj z hladiska celosvetového k prvým odborníkom v tejto oblasti. Známa je jeho práca Chirurgické choroby žaludku a dvanáctníku, kde sa k danej problematike vyjadril: „Patřím, jak známo, mezi tak zvané radikální chirurgy najmě co do therapie vředů duodenálních, $k$ jejichž resekcím jsem se odhodlal již v dobách, kdy se této operace, s malými výjimkami, neodvážil ještě

8 Profesor Čársky neskôr zhodnotil, „[...] že Slovensko umožnilo Kostlivému rozvinút všetky schopnosti, ktorými oplýval, a je otázkou, či by bola vynikla jeho osobnost' takou silou všestrannou v inom prostredí. Nebolo vhodnejšieho človeka pre Slovensko. Muž elegantného zjavu, jemných spoločenských spôsobov a širokého vzdelania všestranného i odborného si podmaňoval l'udí na prvý pohlad, i takých, ktorí s predsudkami zavrhovali všetko, čo bolo české. L'udí tohto typu bolo roku 1919 v Bratislave a na Slovensku mnoho. Kostlivý tým, že budil úctu k sebe, získaval úctu i svojmu národu. “ČÁRSKY 1947, s. 639.

9 Vedenie kliniky v Bratislave mu bolo zverené v konkurencii s takou „európskou kapacitou, ako bola osobnost” doc. Dr. Bakeša." KŇAZOVICKÝ, Ján. Prof. MUDr. Stanislav Kostlivý 1877 - 1946. In BLL, 1947, roč. 27, č. 1, s. n.

10 Bežne sa tu operovali žlčníky, strumy, resekcie čreva a postupne aj resekcie žalúdka. Robili sa torakoplastiky, aj nefrektómie pre tuberkulózu a iné urologické operácie, pričom operácie hernií, varixov dolných končatín a apendektómie bežne prevádzali mladší asistenti.

11 ČÁRSKY 1947, s. 639.

12 KŇAZOVICKÝ 1947, s. n.

13 Slovenský národný archív, f. Expozitúra ministerstva verejného zdravotníctva a telesnej výchovy, k. 2, 3.

14 Kým v roku 1919 bolo na klinike hospitalizovaných 7827 pacientov, roku 1929 ich počet vzrástol na 17123 a v roku 1938 dokonca na 23 030. FALISOVÁ, Anna - DUDEKOVÁ, Gabriela. Úroveň zdravotníctva ako znak vel'komesta. Plusy a mínusy zdravotníckej starostlivosti v Prešporku / Bratislave. In Medzi provinciou a metropolou. Obraz Bratislavy v 19. a 20. storočí. Bratislava : Historický ústav SAV 2012, s. 150. 
téměř nikdo. A tak figuruji v statistice Küttnerově, sestavené $r$. 1912, s 5 resekovanými př́pady na prvním místě. Průběhem let vypracoval jsem si spolu se svými asistenty vlastní přesnou metodiku, která nám dovoluje, resekovati s dobrým výsledkem vředy od kardie až pod papilu Vaterovu, - zákroky tedy, kterých bych se zčásti ještě i před 9 lety, když jsem převzal bratislavskou kliniku, sotva byl odvážil." ${ }^{\text {“5 }}$ Neskôr uviedol, že sa pri liečbe týchto ochorení stal konzervatívnejší a viac opatrný. ${ }^{16}$ „Proto jsem se ve své knize pokusil vylíčiti kolegům i všechny ty těžkosti a obtíže diagnostiky, s kterými jsem se ve své praxi setkal, a vyvarovati je tak omylů, jakých jsem se sám mnohdy dopustil. Snad tedy najde i nechirurg a praktik v mé knížce věci, které mu budou státi za přečtení. Kolegům z povolání však radím, aby se na žaludku a dvanáctníku nikdy nepouštěli do operací, pro něž není dostatečné anatomické a fysiologické indikace. Není uspokojení z takových zákroků, ale ani vděku u pacientů. Než ani o indikovanou resekci nepokoušej se nikdo, kdo nemá dostatečných osobních zkušeností v takových operacích “ [...]. ${ }^{17}$ Kniha Chirurgické choroby žaludku a dvanáctníku bola pôvodne určená ako súčast’ učebnice všeobecnej chirurgie, ktorú pripravoval profesor J. Petřivalský. Vzhl'adom na to, že sa učebnicu nepodarilo vydat' v plánovanom rozsahu, Kostlivý sa rozhodol publikovat' svoju čast' ako samostatnú monografiu. Pripravovaná práca obsahovala cenné výsledky „[...] bádání cizích, z velké části osobní zkušenosti získané průběhem téměř 20 let na bohatém materiálu z Třebíče a Bratislavy. "18 V žiadosti o subvenciu vydanie monografie zdôvodnil: „I při př́sném autokratickém hodnocení myslím a doufám, že práce ta přinese čtenářo̊m dosti nového a zajímavého nejen proto, že publikace podobného thematu a rozsahu $v$ české vědecké literatuře dosud vydána nebyla, ale z toho důvodu, že není - a snad mimo Jedličky ani nebylo - československého chirurga, který by se na uvedeném poli mohl vykázati stejně bohatou osobní zkušeností."19

Profesor Kostlivý sa podujal vybudovat’ prvú slovenskú chirurgickú kliniku a vychovat’ Slovensku vlastných chirurgov. Výchove nového dorastu venoval vel'kú pozornost' a medzi študentmi bol vel'mi oblúbený. Profesor Kňazovický jeho prístup k študentom zhodnotil: „Študentom prednášal s vel'kou láskou a s hlbokou prípravou. [...] Žiaci zbožňovali jeho vybrúsenú, brilantnú reč, ktorá svojou teoretickou a praktickou formou pripravila ich aj bez učebníc ku skúškam. Svoju

15 KOSTLIVÝ, Stanislav. Chirurgické choroby žaludku a dvanáctníku. Bursík \& Kohout: Praha 1929, s. 5.

16 „Než stali jsme se za ta léta v mnohem směru i značně konservativními. Neoperujeme kupř. ulcus simplex na žaludku, ale odkazujeme takové př́pady nejprve k léčení internímu, a operujeme jen tehdy, když se toto léčení ukázalo bezvýsledným, nebo zanechalo těžší anatomické deformace. I při krvácivém vředu zachováváme se dnes již zdrženlivěji, než jsme bývali dř́ve. Naučili jsme se znáti i praeulcerosní stadia a „neurosy“ žaludeční, které jsou klamné tím, že vykazují začasté plnou symptomatologii pravého vředu. Víme dnes, že těmto nemocným prospějeme i tam, kde se sami operace dožadují, energickým odmítnutím zákroku víc, než zbytečnou laparotomií nebo dokonce neodůvodněnou gastroenteroanastomosou."Tamže, s. 5.

17 „Peptický vřed žaludeční není výhradnou doménou chirurgů, ale dá se tu v mnohých případech účelnou interní therapii docíliti velmi pěkných a trvalých výsledků. Nám alespoň je pravidlem, že operujeme zásadnějen vředy kalosní a deformující [...]. Rovněž je nám opětované těžké, nebo i stálé byt' menší krvácení indikací k operativnímu zákroku. Ve všech ostatních případech vředů žaludečních operujeme až tenkráte, když se ukázala bezmocnou i opětovaná léčba interní. Rychleji a lehčeji se odhodláváme k operaci u zjištěných vředů duodenálních, o nichž je známo, že u nich interní therapie selhává velmi často. U peptických vředů jejunálních máme operaci za jediný možný a správný pokus o therapii."Tamže, s. 5-6.

18 Tamže, s. 5-6.

19 AUK, f. RUK, personálne oddelenie - pedagogickí zamestnanci, osobný spis Stanislav Kostlivý, k. 95; Žádost o subvenci na vydání monografie Choroby žaludku a duodena. Dňa 4. 8. 1928. 
učebnú povinnost' ponímal vážne, pred hodinou nebol nikomu prístupný, a celá klinika točila sa okolo prednášok. Skúšky viedol prísne, ale spravodlive a dobromysel’ne. ${ }^{\prime 20}$ Kostlivý sa stal vzorom pre dve generácie slovenských lekárov a jeho povest’ dlho prekonala roky jeho pôsobenia v Bratislave. Tešil sa a podporoval úspech iných. Osobitné miesto v jeho pedagogickom systéme mala výchova slovenského dorastu pre vedeckú prácu. Pod jeho vedením vyrástla nová generácia slovenských chirurgov, ktorí pozdvihli slovenskú chirurgiu na vyššiu úroveň. Vychoval okolo sto chirurgov, osem univerzitných profesorov a šest’ docentov, ktorí sa hrdo hlásili k jeho škole. Záležalo mu na tom, aby na klinických pracoviskách pôsobilo čo najviac Slovákov aj v riadiacich pozíciách. Zásluhou Kostlivého vznikla slovenská chirurgická škola a na Chirurgickej klinike Lekárskej fakulty UK sa vychovali chirurgovia, ktorí postupne obsadili takmer všetky primariáty po celom Slovensku. ${ }^{21}$

K jeho oblúbenosti prispeli aj niektoré výrazné osobnostné črty. Mal kultivované vystupovanie a spoločenskú úroveň. Požiadavky slušného správania a etikety mal v malíčku, takže sa toho ani nemusel kŕčovite pridržiavat'. Z domu mal klasickú dobrú výchovu. Vyznačoval sa vysokou inteligenciou a vel'kou citlivost’ou. Kúzlo osobnosti a aristokratické vystupovanie S. Kostlivého priblížil aj jeho priatel' zo študentských čias, neskorší univerzitný profesor Anton Štefánek. Pri spomienke na profesora Kostlivého uviedol: „Mladý šuhaj, poznačený nevusom flameom, ${ }^{22}$ alebo ako sa pán Tománek neskôr po slovensky vyslovil „čertovským chvostom udretý po líci“, nemohol konkurovat's takými elegánmi, ako bol Kostlivý alebo Kamil Krofta. [...] Ale tuším táto moja bojazlivost' a vel'ká chudoba vzbudila pozornost' starého profesora Němca, vel'kého národovca a ešte väčšieho organizátora tanečných zábav, ktorý vždy dával vol'né vstupenky na plesy a korunu na útraty. Pravda nie zadarmo. Musel som za to vytancovat' podla jeho pokynov dámy vyššieho veku a menšou krásou obdarené. A tak sa zdá, že citlivý Kostlivý si toho všimol a dal sa so mnou do reči. Tak som sa soznámil so Stanislavom, ktorá známost' vyvrcholila neskôr v kamarátstvo a priatel'stvo, trvajúce celých pät'desiat rokov. Čo nás spájalo? On i K. Krofta boli tak trochu aristokrati, aspoň tak sme ich nazývali. Hmotne boli dobre situovaní a povahou svojou zdržanliví i vážni. My, moravskí a západní Slováci, s Dr. Pavlom Blahom, (Hugo) Bezděkom, Berkom atd'. až príliš veselí a tak trocha i l'ahtikári. Ale spojovala nás už vtedy, koncom 19. storočia, národná idea československá a slovanská, ktorá získala v študentskom živote predvojnovej Viedne viditel'ný obsah v aktívnej spolupráci slovanských akademických spolkov. ${ }^{23}$ Po odchode Štefánka z Viedne sa nevideli dlhé roky, ale ich priatel'stvo pretrvalo nad'alej. Podobne Kostlivého hodnotil aj Il'ja Paulíny-Tóth. „Vždy poslúžil dobrou radou, pomocou, všetkým lekárom, ktorí sa naňho obrátili. [...] dbal vel'mi na etiku a morálku lekárskeho stavu, [...] bol oblúbený a vysoko vážený pre svoje

20 KŇAZOVICKÝ 1929, s. n.

21 KOTHAJ 1999, s. 60.

22 „Oheň“, alebo (naevus flammeus), je vrodenou cievnou malformáciou. Lokalizovaná porucha vývoja tkanív sa na koži prejaví už po narodení červeným ložiskom. Podstatou (naevus flammeus) je chorobné nahromadenie tenkých cievok, kapilár v podkoží. Prekrvením týchto patologických cievnych štruktúr nadobúda ložisko charakteristickú červenú až fialovú farbu.

23 „Kostlivý nikdy nezabudol na krásne seansy, ktoré sme mávali vo Viedni, na akademické i veselé rozhovory, výlety a plány do budúcna." In Univ. prof. MUDr. a DrHC. Stanislav Kostlivý. Povereníctvo zdravotníctva v Bratislave. Bratislava, 1947, s. n. Univ. prof. PhDr. A. Štefánek. 
gentlemanstvo, gavalierstvo, a priatel'skú povahu. Bol vždy nestranný a vždy sa vedel povzniest' nad osobné záujmy a bol prístupný odôvodneným argumentom. ${ }^{24}$ Bol to profesionál s hlbokým sociálnym cítením, ktorý sa vyznačoval priatel’ským prístupom k pacientom i kolegom. Miloval hory, s rodinou precestoval celú Európu, hudbu a po večeroch hrával na klavíri s manželkou. Vel'mi dobre kreslil a napriek množstvu d’alších záujmov, žil najmä pre chirurgiu. Na pracovisku trávil väčšinu času, len pred večerou si posedel s priatel'mi v kaviarni Berlínka, kde si prečítal noviny. ${ }^{25}$ Kostlivý vedecké poznatky rozdával bez výhrad, ale nikomu ich nevnucoval. Ponechával svojim žiakom značnú slobodu pod podmienkou, že neopúštali štandardné chirurgické normy. Študentom zdôrazňoval potrebu pracovitosti a zároveň tvorivosti.

Významný je vklad Kostlivého pri budovaní Lekárskej fakulty UK. Zastával názor, že UK sa buduje najmä pre potreby slovenského národa a lekárska fakulta pre rozvoj jeho zdravotníctva s dôrazom na výchovu najmä slovenského lekárskeho dorastu. Túto myšlienku presadzoval bez nacionálnych predsudkov. ${ }^{26}$ Kostlivý zastával funkciu prorektora UK a v školskom roku 1923/1924, ked’ bol rektorom UK, podarilo sa dobudovat' lekársku fakultu. Vyučovanie prebiehalo vo všetkých ročníkoch. Zriadením Lekárskej komory pre Slovensko a Podkarpatskú Rus so sídlom v Bratislave sa Kostlivý stal jej prvým predsedom. Funkciu predsedu zastával až do svojej rezignácie v apríli 1939. Kostlivého zásluhou vznikla v Bratislave, neskôr v Košiciach filiálka Lekárskej záložne ${ }^{27}$ a sociálny fond na podporu vdov a sirôt a práceneschopných lekárov. Dlhé roky stál na čele Spolku slovenských lekárov v Bratislave. Bol riadnym členom mnohých vedeckých a odborných spoločností a nositelom viacerých vyznamenaní.

\section{Osud profesora Kostlivého po roku 1939}

Profesor Kostlivý prežil na Slovensku najkrajšie roky z hladiska profesionálneho i osobného. Politické udalosti po roku 1939 znamenali osudný zlom v jeho živote. Aj ked' mu sl'ubovali stále miesto, nakoniec musel odíst'. V marci 1941 MŠNO v súvislosti s pôsobnost'ou profesora Kostlivého rozhodlo: „V smysle dohody medzi Slovenskou republikou a Nemeckou ríšou, uzavretej 6. decembra 1940, ponechávam Vás ako zamestnanca českej národnosti v službách Slovenskej republiky do 30. júna 1942. Ministerstvo školstva a národnej osvety v Prahe o tom súčasne upovedomujem. ${ }^{\prime 28}$ Ale už o necelé tri mesiace neskôr sa situácia zmenila a predchádzajúce rozhodnutie MŠNO bolo anulované. S. Kostlivý mal byt' daný k dispozícii Ministerstvu školstva a národnej osvety v Prahe 30. septembra 1941.

Profesorský zbor lekárskej fakulty sa na svojom zasadnutí 18. júna 1941 uzniesol požiadat' o vysvetlenie, z akých dôvodov a pohnútok zrušilo MŠNO svoj pôvodný dekrét, podla ktorého mal byt' Kostlivý ponechaný v službách Slovenskej republiky do konca júna 1942. Zároveň

24 Univ. prof. MUDr. a DrHC. Stanislav Kostlivý. Povereníctvo zdravotníctva v Bratislave. Bratislava 1947, s. n. Dr. Paulíny-Tóth, Ilja.

25 ČÁRSKY, Konštantín. Osobnost’ profesora Stanislava Kostlivého. In $B L L, 1997$, roč. 98, č. 9, s. 459.

26 TIBENSKÝ - PÖSS 1999, s. 90.

27 Predsedom správy tohto peňažného ústavu bol od založenia až do roku 1939. In Univ. prof. MUDr. a DrHC. Stanislav Kostlivý. Povereníctvo zdravotníctva v Bratislave. Bratislava, 1947, s. n.

28 AUK, f. RUK, personálne oddelenie - pedagogickí zamestnanci, osobný spis Stanislav Kostlivý, k. 95; 
jednohlasným uznesením žiadal, aby bol Kostlivý v záujme fakulty ponechaný v službách Slovenského štátu. ${ }^{29}$ Za ponechanie Kostlivého apeloval aj dekan Lekárskej fakulty a žiadal, aby Kostlivý zostal na Slovensku v pôvodnom zaradení. Ako dôvod uvádzal, že mimoriadne vel'ký počet chirurgov bol povolaný do vojenských služieb. „Z uvedených dôvodov služieb prof. Dr. Stanislava Kostlivého potrebujeme, hlavne k účelom verejne-zdravotným, aby nebol narušený chod chirurgickej kliniky počas vojny a i z dôvodov učitel'ských, ked'že prof. sbor prosí Ministerstvo

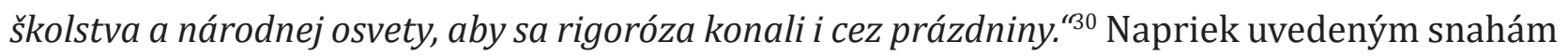
MŠNO svoje rozhodnutie nezmenilo. „Pán minister svoje opatrenie, ktorým prof. Dr. S. Kostlivého dal Ministerstvu školstva a národnej osvety v Prahe $k$ dispozícii, ponechal v platnosti. ${ }^{31}$ Nakoniec dekanát Lekárskej fakulty v septembri 1941 potvrdil, že S. Kostlivý odchádza začiatkom októbra 1941 so svojou rodinou do protektorátu Čechy a Morava a predmetné potvrdenie vydáva ako doklad na preukázanie sa pred úradmi. ${ }^{32}$ Kostlivý vzhladom na uvedené skutočnosti rezignoval. V júni 1941 ospravedlnil svoju účast’ na zasadaní zboru Lekárskej fakulty. „Necítim sa už morálne oprávneným zasahovat' - bárs aj len prítomnostou a prípadným hlasovaním - do záležitosti fakulty, ktorú $v$ krátkej dobe mám definitívne opustit'. ${ }^{\prime 3}$

Okolnosti jeho odchodu z Bratislavy, ked’ bol ešte plný síl, opísal profesor Dr. Jaroslav Sumbal, prednosta Propedeutickej kliniky II. internej kliniky Lekárskej fakulty UK. „Všichni jsme znali jeho nekompromisní národovectví, věděli jsme o tom, že byl volnomyšlenkářem, že byl členem klubů a společností, které platily jako neodpustitelný hřích v očích tehdejší vedoucí politické strany. Všichni o něm věděli, že stál v ostrém rozporu s vládnoucí slovenskou stranou, a přece tato nová vládnoucí strana ponechala Kostlivého na jeho místě, jelikož si byla vědomá jeho významu a práce, kterou pro Slovensko udělal. Nebylo to proto, že by nebylo náhrady za Kostlivého, ale jedině proto, že jméno Kostlivého bylo pojmem známým po celém Slovensku. A proto neodvážili se Kostlivého napadnout ani ti nejzarputilejší. Teprve později, když se osud zde žijících Čechů dostal do rukou Tuky a jemu podobných, když viděl, co se kolem něho děje, teprve tehdy prof. Kostlivý ustoupil a nedovolil svojim přečetným známým, aby se pokusili znemožnit rozhodnutí tehdejších některých členů vlády. Nepomohly ani demonstrace a memorandum studentů a prof. Kostlivý odešel do Prahy, když splnil svůj úkol. ${ }^{\text {‘34 }}$ Profesor Čársky v súvislosti s odchodom Kostlivého do Prahy uviedol, že bol človekom zásad, ktorých sa pridržiaval až fanaticky, často na vlastnú škodu. Ponížit’ sa preňho bol neznámy pojem. Zlomený odchádzal z Bratislavy so slovami: „Ne prosit nebudu. Půjdu tam, kde odešli všichni moji, tam je moje místo. “Čársky konštatoval, že ne-

29 AUK, f. RUK, personálne oddelenie - pedagogickí zamestnanci, osobný spis Stanislav Kostlivý, k. 95; Prof. Dr. S. Kostlivý - oddisponovanie. Dňa 19. 6. 1941.

30 AUK, f. RUK, personálne oddelenie - pedagogickí zamestnanci, osobný spis Stanislav Kostlivý, k. 95.

31 AUK, f. RUK, personálne oddelenie - pedagogickí zamestnanci, osobný spis Stanislav Kostlivý, k. 95; Prof. Dr. S. Kostlivý - žiadost' profesorského sboru lekárskej fakulty o dalš̌ie pôsobenie. Dňa 13. 8.1941.

32 AUK, f. RUK, personálne oddelenie - pedagogickí zamestnanci, osobný spis Stanislav Kostlivý, k. 95; Prof. Dr. Stanislav Kostlivý - potvrdenie o oddisponovaní. Dňa 25. 9. 1941.

33 „Ospravedlňujem svoju neprítomnost’ na zajtrajšim zasedaní sboru naši fakulty tým, že som bol novým dekrétom pána ministra školstva a národnej osvety [...] prepustený zo služieb Slovenskej republiky." AUK, f. RUK, personálne oddelenie - pedagogickí zamestnanci, osobný spis Stanislav Kostlivý, k. 95.

34 Univ. prof. MUDr. a DrHC. Stanislav Kostlivý. Povereníctvo zdravotníctva v Bratislave. Bratislava 1947, s. n. SUMBAL, J. Prejav predsedu Spolku Slovenských lekárov v Bratislave. 
poznal poníženost' ani ako taktiku a keby mal aspoň náznak tejto vlastnosti, pravdepodobne by neodišiel zo Slovenska. ${ }^{35}$

S. Kostlivý bol po príchode do Prahy zlomený na tele i na duši. MŠNO rektorátu Slovenskej univerzity oznámilo: „Podl'a noty ríšskeho zahraničného úradu [...] prevzalo Ministerstvo školstva a národnej osvety v Prahe riadneho profesora MUDr. Stanislava Kostlivého [...] do svojich služieb

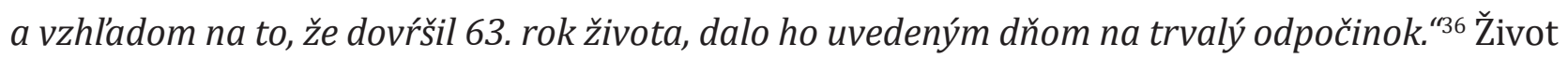
v Prahe sa vyvíjal úplne odlišne ako v Bratislave. Z človeka zaneprázdneného od rána do večera sa naraz stal penzista, ktorý nemal „nič na práci.“ Pripadal si zbytočný, nebol zvyknutý márnit’ čas nič nerobením. Ani finančne nebol na tom najlepšie. Počas svojej profesionálnej kariéry na Slovensku nezískal bohatstvo. Žil z profesorskej penzie a jeho finančná situácia v Prahe nebola závideniahodná, ako by sa bolo patrilo na chirurga, ktorý viedol klinické pracovisko a mal rozsiahlu prax. ${ }^{37}$ Slovensku venoval 22 rokov svojho profesionálneho života a so sebou zobral vedomie dobre vykonanej práce.

Jeho zdravotný stav sa zhoršoval, zrejme k tomu prispela aj skutočnost', že bol silný fajčiar. Oslobodenie vlasti, pocta Slovenskej univerzity ho prechodne vzpružili, ale nemal už dostatok síl na d’alšie plány. Priatelia a žiaci ho volali naspät' na 1. chirurgickú kliniku Lekárskej fakulty do Bratislavy. V tom období už bol t’ažko chorý, mlčanlivý a ani jeho najbližší nevedeli, či si bol vedomý blízkej smrti. Krátko nato bol hospitalizovaný na klinike akademika Charváta, kde aj 7. decembra 1946 zomrel. ${ }^{38}$

\section{Žiak profesora Kostlivého - Konštantín Čársky}

Konštantín Čársky sa narodil 4. apríla 1899 v Gbeloch ako najmladší zo štyroch detí v rodine rol'níka. Na detstvo mal nádherné spomienky. L’udovú školu ukončil v Gbeloch. Rodičia nemali prostriedky na štúdium mladšieho syna. Ujal sa ho starší brat Ludvík, ktorý pôsobil ako lekár v Nitre a finančne ho podporoval. Konštantín Čársky navštevoval v rokoch 1912 - 1913 gymnázium v Nitre. Ked' Dr. Čársky prijal ponuku pracovat' na chirurgickej klinike v Kluži, poslal Konštantína na gymnázium do Skalice, kde boli preňho začiatky vel'mi t’ǎké. Neskôr sa vo svojich pamätiach vyjadril, že v štúdiu nepatril medzi najlepších žiakov, ale ani tých najhorších. Štúdium mu však nerobilo t’ažkosti. „Školy boli mad'arské, slovensky sme sa učili len katechizmus. Mali sme vel'mi dobrého, múdreho farára, Pavla Blahu, ku ktorému chodili všetci predprevratoví i poprevratoví úradníci po rozumy. ${ }^{39}$ Na želanie matky prestúpil zo skalického gymnázia na reholné gymnázium v Trnave, ktoré bolo prípravkou na štúdium teológie. Maturoval v roku 1917 a krátko po skončení štúdia narukoval do armády. Po základnom výcviku pri Ostrihome

35 ČÁRSKY 1947, s. 640.

36 AUK, f. RUK, personálne oddelenie - pedagogickí zamestnanci, osobný spis Stanislav Kostlivý, k. 95; Prof. MUDr. S. Kostlivý, danie k dispozícii, prevzatie do služieb Mšano v Prahe. Dňa 8. 11. 1941.

37 Univ. prof. MUDr. a DrHC. Stanislav Kostlivý. Povereníctvo zdravotníctva v Bratislave. Bratislava 1947, s. n. SUMBAL, J. Prejav predsedu Spolku Slovenských lekárov v Bratislave.

38 AUK, f. RUK, personálne oddelenie - pedagogickí zamestnanci, osobný spis Stanislav Kostlivý, k. 95.

39 SÝKORA, František. Cesty k dnešnej medicíne. Martin : Osveta, 1990, s. 100. Rozhovor s profesorom MUDr. Konštantínom Čárskym. 
a absolvovaní rýchlej školy pre dôstojníkov slúžil vo Vodných kasárňach na Dunajskom nábreží, kde vykonával strážnu službu. Koncom roka bol odvelený na front do Albánska. Ned'aleko gréckych hraníc zotrval až do konca vojny a tu prekonal aj tažkú maláriu. ${ }^{40}$ Po návrate domov aj napriek matkinmu želaniu, aby sa venoval štúdiu teológie, pod vplyvom staršieho brata - lekára, v ktorom videl vel'ký vzor, ale aj pre túžbu pomáhat' chorým sa rozhodol pre medicínu. ${ }^{41}$ V januári 1919 bol prijatý na Lekársku fakultu Karlovej univerzity v Prahe. Zaujímavý je pohlad na jeho študentské začiatky. Pôvodne chcel študovat’ na Lekárskej fakulte vo Viedni, ale pod vplyvom „autorít“ zmenil názor. „[...] náš farár Blaho a skalický Okánik ma l'ahko prehovorili, aby som išiel do Prahy. ${ }^{42}$ [...] Bol som jedným z prvých Slovákov, ktorí sa po prevrate zapísali na lekársku fakultu; [...] V školskom roku 1918 - 1919 bolo v Prahe asi 23 slovenských vysokoškolákov. Viem to podl'a toho, pretože sme boli všetci pozvaní na hrad k prezidentovi Masarykovi. Stáli sme $v$ rade, ja som bol posledný, lebo som bol najmenší a azda aj najchudobnejší, oblečený len v starej vojenskej blúze so strhnutými dištinkciami. Prezident išiel od jedného k druhému, rozprával sa s vysokoškolákmi, tomu poznal otca, tomu strýca - ved' tam bola slovenská elita - a ja som mal len strach, či príde až ku mne. Ale prišiel, spýtal sa ma, odkial' som. Ked' som povedal naším nárečím „ze Gbelú ze Záhorá“ - spisovnú slovenčinu som ešte dobre neovládal - potlapkal ma po pleci. Potom nám pod'akoval, že sme prišli a študujeme, má z nás radost', ale najmä sa raduje tomu poslednému, svojmu krajanovi z Gbiel. Ako šest'ročný vraj išiel z Kopčian so svojou matkou do Šaštína na pút' a v Gbeloch sa zastavili. Vraj sa na to dobre pamätá. Bol som vel'mi št'astný, že prezident $v$ rozlúčke spomenul práve moje rodisko. "43 Čársky v Prahe absolvoval tri ročníky a v roku 1921 prestúpil na Lekársku fakultu UK do Bratislavy, kde v roku 1924 promoval.

Po promócii nastúpil do Ústavu patologickej anatómie LF UK u profesora A. Spilku. Dopoludnia vykonával pitvy a popoludní pracoval v laboratóriu. Jeho túžbou bolo venovat' sa klinickej medicíne a o rok neskôr na radu vtedajšieho asistenta chirurgie Dr. Kňazovického sa začal uchádzat' o prácu na Chirurgickej klinike profesora Kostlivého. Do nového zamestnania nastúpil začiatkom decembra 1925, kde zo začiatku vykonával patologicko-anatomické práce, neskôr sa začal venovat’ chirurgii. V roku 1929 z vlastných úspor absolvoval prvú študijnú cestu do USA. Počas niekol'kých mesiacov navštívil viaceré klinické pracoviská a oboznámil sa s progresívnymi metódami liečenia. Vel'kým prínosom bola preňho stáž u svetoznámeho neurochirurga profesora Cushinga na Harvardskej univerzite a štúdium na Clevelandskej klinike. Na Mayovej klinike sa oboznámil s endokrinnou chirurgiou, ktorej sa neskôr intenzívne venoval. ${ }^{44}$

40 ČÁRSKY, Konštantín. Chirurg spomína. Bratislava : Slovenský spisovatel,' 1987, s. 290.

41 „Chorlavá mamička chcela aj po vojne, aby som išiel študovat’ do Ostrihomu za kňaza. Ja som sa však už v Albánsku rozhodol pre štúdium medicíny. Mal som predsa vzor aj v našom Ludvíkovi, ktorý sa stal po skončení vojny riaditelom nitrianskej župnej nemocnice a zároveň primárom chirurgického oddelenia. [...] Aj on mi odporúčal íst' študovat' medicínu. Poslúchol som hlas srdca i rozumu." MORAVEC, Rudolf a kol. $Z$ dejín chirurgie na Slovensku. Bratislava : Pramene 1990, s. 124.

42 Podarilo sa mu získat' podnájom. „Prostredníctvom poslanca Červinku a Rotnágla, vel'kého priatel’a Slovákov, dostal som aj byt [...]." SÝKORA 1990, s. 101; „Konšta náhodou dostáva slušnejšie bydlisko u vdovy po známom českom maliarovi Meixnerovi. Tu poznáva český umelecký a literárny život." In Gbelský chlapec. Krátky film zo života počas dlhých pät'desiatich rokov v II úsekoch. Neskôr býval v Štefánikovej koleji.

43 SÝKORA 1990, s. 101.

44 FALISOVÁ, Anna. Konštantín Čársky. In MICHÁLEK, Slavomír - KRAJČOVIČOVÁ, Natália a kol. Do pamäti národa. 
V roku 1931 získal docentúru za vedeckú prácu z oblasti septickej chirurgie. Politické udalosti v roku 1938 naštartovali aj kariérne zmeny v živote K. Čárskeho. Roku 1938 bol vymenovaný mimoriadnym, o rok neskôr riadnym profesorom. Dočasne pôsobil ako prednosta Kliniky chirurgickej propedeutiky a ortopédie, kde sa zaoberal liečením poúrazových stavov končatín, tuberkulózou kĺbov, kostí a i. Po mníchovskom verdikte a vyhlásení mobilizácie narukoval do Vrútok a v hodnosti podplukovníka pôsobil ako velitel' zdravotnej divízie. Po odchode profesora Kostlivého do Česka v roku 1941 prevzal vedenie I. chirurgickej kliniky.

Osobný život K. Čárskeho sa zmenil po jednej nečakanej udalosti. V polovici 30. rokov ochorela najmladšia dcéra profesora Kostlivého a jej diagnóza znela - t’ažká otrava krvi. Po dôkladnom vyšetrení bola nutná operácia. Jej otec, ktorý tol'kým l’ud’om prinavrátil zdravie, „[...] operácie vlastnej dcéry sa vzdal. ${ }^{“ 5}$ Známou tradíciou v lekárskom prostredí bolo, že pri ochorení člena rodiny ho ošetroval niekto cudzí. Vol'ba padla na mladého asistenta K. Čárskeho. Operácia bola náročná, Čársky uskutočnil pät’ operatívnych zákrokov, ktoré úspešne zvládol. Liečenie bolo zdĺhavé a pri lôžku pacientky sedávala staršia sestra L'udmila, ktorá pôsobila ako profesorka slovenčiny a francúzštiny na dievčenskom gymnáziu. Čárskeho najstaršia dcéra Kostlivého zaujala a po čase sa zblížili. V roku 1936 sa zosobášili. „Skalický farár Caban, dobrý priatel’ Konštíka z vd’ačnosti, lásky a osobného priatel'stva svadbu i hostinu vystrojil. [...] Narodila sa im dcéra Milica. Neskôr sa narodili d’alšie deti synovia Milan, Konštantín, čiže Kostá, Stanislav a napokon Ivan Václav. Všetky Konštove deti krstil dôstojný pán Dr. L’udovít Okánik, ktorý si o sebe vravieval s humorom, že je Čárskych hausprelátom." ${ }^{\text {"46 }}$

Vo vedeckovýskumnej práci a klinickej praxi sa K. Čársky zo začiatku venoval septickej, najmä brušnej chirurgii so zameraním na gastrointestinálny trakt. Ako žiak profesora Kostlivého vo svojej práci bol ním vel'mi ovplyvnený a špecializoval sa najmä na abdominálnu chirurgiu. Z tejto problematiky uverejnil viac ako 50 prác, najmä kauzistického charakteru. ${ }^{47}$ Stal sa priekopníkom správneho ošetrovania septických chirurgických ochorení a so svojimi prácami mal vel'ký ohlas aj v zahraničí. Predchádzajúce skúsenosti nadobudnuté na prvom pracovisku boli preňho vel'kou výhodou. Vd'aka tomu vedel z výteru rany si sám vypestovat' baktérie, určit' príčinu choroby a mohol nasadit' cielené antiseptiká. Pracoval rýchlo a nebol závislý na práci laborantov. ${ }^{48}$ Osobitnú pozornost' venoval rekonštrukčnej chirurgii. Plastická chirurgia v tomto období ešte nebola samostatným odborom. Okrem mnohých výkonov v plastickej chirurgii tváre uskutočnil 30 antetorakálnych ezofagoplastík (náhrad pažeráka) podla Roux-Sercena bez jediného exitu. V roku 1948 získal študijný pobyt v USA financovaný z prostriedkov Rockefellerovej nadácie. Po návrate domov sa začal zameriavat’ na špeciálnu chirurgiu. Vel'kú pozornost' venoval problematike nádorových ochorení hrubého čreva, prevencii rakoviny žalúdka, chirurgickej liečbe žalúdočného a dvanástnikového vredu. Špecializoval sa aj na otázky endokrinného systému, zaujala ho najmä chirurgia štítnej žlazy. Jeho oblúbené operácie boli

Osobnosti slovenských dejín prvej polovice 20. storočia. VEDA : Bratislava 2003, s. 96.

45 Gbelský chlapec, s. n.

46 Gbelský chlapec, s. n.

47 AUK, fond RUK, personálne oddelenie - pedagogickí zamestnanci, osobný spis Konštantín Čársky, k. 26.

48 KOTHAJ 1999, s. 81. 
strumektómie. Rozpracoval nielen technickú stránku chirurgického výkonu, ale aj predoperačnú prípravu a pooperačné doliečenie pacientov. V tejto oblasti dosiahol vynikajúce výsledky. Ako chirurg sa vyznačoval precíznou operačnou technikou. Z jeho iniciatívy sa od roku 1948 začali každoročne začiatkom decembra organizovat’ tradičné Kostlivého chirurgické dni, ktoré sa mali stat' trvalou spomienkou na osobnost' a dielo profesora Kostlivého. ${ }^{49}$ Rezolúcie Kostlivého chirurgických dní neraz prispeli k uplatňovaniu progresívnych myšlienok v zdravotníctve.

Profesor Čársky bol vynikajúcim pedagógom na Lekárskej fakulte UK. Vychoval nielen stovky odborných lekárov, ale aj mnoho vedcov. Podiel’al sa aj na habilitáciách z chirurgických disciplín. Prednášal až do svojho odchodu do dôchodku. Publikoval vyše 400 odborných štúdií, zdravotno-osvetových článkov, vystupoval v rozhlase, televízii a i. Na Lekárskej fakulte UK zastával funkciu dekana v rokoch 1940/1941 a 1941/1942, hlavným chirurgom pre Slovensko bol v rokoch1950 - 1970, pôsobil ako člen poradného zboru hlavného chirurga Ministerstva zdravotníctva ČSR v Prahe a vo viacerých domácich a zahraničných vedeckých spoločnostiach. Zúčastňoval sa aktívne nielen slovenských a českých, ale aj mnohých medzinárodných podujatí.

\section{K. Čársky a zdravotno-osvetová práca}

Osobitnú kapitolu profesionálnej kariéry K. Čárského tvorí rozsiahla zdravotno-osvetová práca. Vyjadril v nej postoj k riešeniu mnohých závažných zdravotno-osvetových problémov, návod, ako si udržat' zdravie a predchádzat' mnohým ochoreniam. S cielom zvýšit' zdravotné uvedomenie obyvatel'stva v roku 1944 publikoval monografiu O chorobách a lekároch, ktorá vznikala v priebehu desiatich rokov. Obsahuje populárne prednášky, ktoré sa dotýkali najmä oblasti chirurgie. Nechcel svojich čitatelov naučit’ choroby liečit', „,...] ale choroby chápat' a rozumiet' ich podstate i liečebnému postupu [...]. Liečenie patrí lekárovi, chorý má vediet', kedy ho má vyhl'adat'. Svojou knižkou mienim prispiet’ na zvýšenie zdravotnej úrovne našej pospolitosti. ${ }^{\text {‘50 }} \mathrm{K}$. Čársky bol radikálnym zástancom popularizácie medicíny. V predslove knihy upozornil na nutnost’ zdravotno-osvetovej práce. „Náhl’ady o účelnosti popularizácie medicíny sa rozchádzajú. Sú lekári, ktorí zastávajú náhl’ad, že je ich stavu nedôstojná a veci škodlivá. Pokladajú pod svoju dôstojnost' prednášat'alebo písat' laickému publiku. Sú i takí, ktorí tvrdia, že popularizácia medicíny šíri fušerstvo, učí povrchnostiam, vychováva hypochondrov a podobne. Zastávam stanovisko opačné. Bez popularizovania vedy niet vzdelanostnej úrovne. ${ }^{\text {"51 }}$

49 Poslanie chirurgických dní Kostlivého špecifikoval na prvom ročníku profesor Podlaha, vtedajší predseda Čsl. chirurgickej spoločnosti. Ich hlavným ciel'om je: 1. byt' trvalou spomienkou na osobnost' a dielo profesora Kostlivého, 2. rozvoj spolupráce medzi slovenskými a českými chirurgmi, symbolom spolupráce a zbližovania chirurgov z Česka a Slovenska, 3. prezentácia výsledkov vedeckej práce a vlastných skúseností. „Kostlivého chirurgické dni mali dávat’ to, čo nové veda prináša praxi, mali sa stat' pružným a obsažným zdrojom informácii o súčasných problémoch a smeroch v chirurgii, najmä v tesnom vztahu k potrebám širokého zdravotníckeho terénu." Stanovený ciel' ako konštatoval profesor Kratochvíl sa podarilo naplnit'. KRATOCHVÍL, Milan. Dvadsat' rokov chirurgických dní prof. Kostlivého. In Pokroky v chirurgii XX. Práce priatelov a žiakov školy Kostlivého, prednesené na XX. Chirurgickom dni 9. decembra 1966 v Bratislave, ktorý usporiadala Československá chirurgická spoločnost', sekcia československej lekárskej spoločnosti J. E. Purkyňu. Bratislava : Obzor, 1967, s. 8.

50 ČÁRSKÝ, Konštantín. O chorobách a lekároch. Bratislava : Slovenský rozhlas, 1944, s. 8.

51 „Škola popularizuje v najširšej miere. [...] Fušerstvo, mastičkárstvo, okurovanie, zaklínanie a hriešna nedbalost' je dôsledkom nevedomosti, ktorá je vel'ká i u našej inteligencie, hrozivá však u pospolitého l'udu. Nie je zriedkavá otázka kamaráta, advokáta, profesora, položená lekárovi: „Prosím táa, pán doktor, na ktorej strane to vlastne bolí 
Upozorňoval na nevedomost' širokých vrstiev obyvatel'stva a presadzoval názor, že zdravovedu je potrebné sprostredkovat' jednoduchou a prístupnou formou. ${ }^{52}$ „Želal by som si, aby každý člen nášho národa vedel aspoň polovicu toho o zdravovede, kol'ko vie o náboženstve a cirkevných predpisoch. Vedomosti neprichádzajú samy, od seba. Niekol'kými prednáškami do rádia, alebo za rok raz prednesenými úvahami $v$ Červenom kríži zdravotnú vzdelanost' nášho národa podstatne nezvýšime. Zdravoveda sa musí šírit' metodicky, pravidelne a často, slovom i písmom, formou srozumitel'nou a l'udu prístupnou. Nemáme učit'l'ud, ako sa má liečit', ale máme sa usilovat' naučit' ho chápat' podstatu choroby. Máme mu prijatel'nou formou predniest' základné pojmy hygieny, preventívnej medicíny. [...] Máme l’ud naučit' poznat', čo má pokladat’ za vec vážnu, kedy nemá otálat', ale dovolávat' sa odbornej rady." ${ }^{\text {"53 }}$

Práca bola vydaná počas vojny a výrazne predstihla dobu. Monografia je progresívna, vidiet', že otázky zlepšenia zdravotného stavu širokých vrstiev obyvatel'stva patrili k jeho prioritám. Počas lekárskej praxe prichádzali za ním pacienti rôznych sociálnych vrstiev a s rôznymi zdravotnými problémami. Ako lekára ho nenechalo lahostajným, že mnohí z jeho pacientov pri dodržiavaní základných zdravotných pravidiel mohli chorobám predíst'. Práca má dôležitý význam z hladiska prevencie chorôb. Preventívne lekárstvo nebolo súčastou vtedajšej medicíny, nedostatok lekárov pretrvával nad’alej a zdravotníctvo zápasilo s mnohými problémami.

Snahu zvýšit' zdravotné povedomie zdôraznil aj v učebnici z roku 1953 Chirurgia pre stredné zdravotnícke kádre, ktorej bol editorom. „[...] kniha je aj pomôckou pre učitelov zdravovedy a pracovníkov zdravotníckej osvety. Je vhodná pre poslucháčov stredných škôl, ktorí mienia študovat' medicínu, ale daktoré state budú zaujímat' i čitatelov so širším všeobecným vzdelaním, ktorí chcú hlbšie nahliadnut' do chirurgických problémov. [...] sme presvedčení, že naša kniha splní svoj ciel,' ked'že učí poznávat' choroby, radí, ako sa im bránit' a ako ich liečit'.54

Popularizačné články zo zdravovedy uverejňoval pravidelne v mnohých periodikách, ale nová etapa v oblasti zdravotno-osvetovej práci u profesora Čárského nastala po odchode do dôchodku. Ked' dovŕšil sedemdesiatku, cítil sa zdravý, plný síl a požiadal o predíženie pôsobenia na I. chirurgickej klinike. Jeho žiadosti vyhoveli, ale o rok neskôr sa pomery na pracovisku zmenili. ${ }^{55}$ Nemohol nad'alej na klinike pôsobit' ani ako konzultant a odišiel do dôchodku. Vel'mi t’ažko sa vyrovnával s novou skutočnostou. Nechcel byt' zbytočným a sediet' so založenými rukami. Po dvoch rokoch vnútorného zápasu si uvedomil, že môže pokračovat' v šírení zdravotno-osvetovej práce a zrazu jeho život získal nový zmysel.

ked’ má človek zapálené slepé črevo?" Čo má vediet' prostý človek, ked’ sú takéto vedomosti človeka s akademickým vzdelaním? Kol'ko desiatok a stovák mladých l’udí zomiera každoročne na zápal slepého čreva len preto, že nemajú ani tušenia o jeho symptomatologii!" Tamže, s. 5-6.

52 „Vel'ká je zaostalost' nášho l’udu v zdravotných veciach. Muzeálne rarity zanedbaných onemocnení sú u nás časté. Hernia, siahajúca po kolená a nosená 20 rokov, lipom v krajine skapulárnej, vážiaci 5 kg, ktorý pacient nosí desiatky rokov ako plecniak, nie je vzácnostou." Tamže, s. 7.

53 Tamže, s. 7.

54 ČÁRSKY, Konštantín. Chirurgia pre stredné zdravotnícke kádre. Martin : Osveta, 1953, s. 6.

55 AUK, fond RUK, personálne oddelenie - pedagogickí zamestnanci, osobný spis Konštantín Čársky, k. 26. Čársky, K. Žiadost' o predíženie dôchodku. Stanovisko dekana a rektora. 
Písal odborné články, vystupoval v rozhlase, televízii, značnú pozornost' venoval osvete v oblasti zdravého stravovania, zlepšenia celkového životného štýlu. Stravovacie návyky obyvatel'stva sa výrazne zmenili a na rozdiel od predchádzajúceho obdobia zdravotníctvo zápasilo s opačným problémom. ${ }^{56}$ Konzumácia vysokokalorických, mastných jedál, sedavý štýl života a i. sa odzrkadlili aj na vzostupe civilizačných chorôb. V jednom zo svojich článkov v roku 1972 upozorňoval na dôležitost' „rozumnej životosprávy“, kde varoval pred prejedaním sa mastnými pokrmami a nedostatkom pohybu. Jeho postoje nestratili nič zo svojej aktuálnosti ani v súčasnosti. „Nezabúdajme, že za svoje zdravie sme zodpovední sebe, rodine a spoločnosti. Každý z nás má už dnes dost' životných skúseností, aby vedel posúdit' význam rozumnej životosprávy pre uchovanie a zveladenie svojho zdravia. Rast sociálneho a materiálneho blahobytu je spätý so vzostupom tzv. civilizačných chorôb. Menej sa pohybujeme, menej fyzicky pracujeme. Všade sa vozíme autobusmi, trolejbusmi, električkami, vlaky i lietadlá sú preplnené. [...] A vol’ný čas? Dvoj - a cez sviatky až trojdňové dni pracovného pokoja sa už vžili, pokladajú sa za samozrejmost'. No l'udia ich trávia pri preplnených stoloch, na posedeniach pri televízoroch miesto toho, aby sa tešili z prírodných krás, venovali sa záhradkárstvu a pod. Potom nadmerne tlstnutie, predčasná artérioskleróza, srdcové infarkty, psychoneurózy a farmakofágia hltanie liekov sú následkom zlozvykov, spojených so stravovaním a neraz aj s neúčelným využívaním vol’ného času. Pravda pri vzniku všetkých spomenutých kazov a výkyvov v l'udskom zdraví zavážia rozličné faktory. No v poprede príčin je prejedanie sa mastnými potravinami a cukrami, obmedzenie aktívneho pohybu a zavše sklon $k$ osobným, rodinným a spoločenským rozoprám rušiacim vzájomné medzil'udské vztáahy. [...] Aj vol'ný čas väčšina trávi pri televízore a bohato obložených stoloch. Nuž účinným preventívnym opatrením je obmedzit' prejedanie a zintenzívnit' pohyb! "57 $^{\text {(57 }}$

Poukazoval aj na riziká spojené s chirurgickou liečbou obéznych pacientov. „Neobstojí ono príslovie, podla ktorého vraj v čase núdze: »Kým tlstý schudne, zatial' chudý zomrie. "Skutočnost' je iná. L'udia chudí, svalnatejší, šlachovitejší sú zdravší a oproti chorobám odolnejší. Chirurgovia nemajú radi tlstých pacientov. Rany sa im pomalšie hoja, častejšie zbierajú a dakedy sa po zakašlaní kýchnutí rozpadnú, napriek dobrému zošitiu. V hrubých vrstvách tukového tkaniva sa zle hladajú dôležité útvary, ktoré chirurg musí chránit,' ošetrit'alebo odstránit'. Tzv. »panský pacient « má vždy viac operačného rizika ako chudší, svalnatý, šlachovitý robotník alebo rol'ník. “58

Ako chirurg s dlhoročnou praxou varoval pred konzumáciou vysokokalorických jedál, ktoré sa podieláli aj na tvorbe žlčových kameňov a kardiovaskulárnych ochoreniach. „Nadmerným prekrmovaním mastnými jedlami pri nedostatočnom fyzickom pohybe, nám pribúda chorých na žlčové kamene, najmä u ženského pohlavia. I ked'strava nie je jediným činitelom pri ich tvorení,

56 „Podvýživa a častejšie jednostranná výživa mala za následok krátky priemerný l'udský vek, slabšiu stavbu tela, častý výskyt tuberkulózy, anglickej choroby, rôzne stupne kretenizmu a zníženú odolnost' oproti infekčným chorobám. Súčasne všeobecne zvýšenie životnej úrovne, do ktorej spadá aj kvalitnejšia a výdatnejšia strava, sa prejavuje niekol'kými skutočnost'ami. Priemerný l'udský vek vyskočil zo 45 na 70 rokov. Deti sú takmer vždy väčšie a zdatnejšie ako rodičia. Infekčné choroby sa vyskytujú iba roztrúsene, sporadicky a nie v epidémiách. Podstatná zmena v stravovaní má aj svoje negatívne stránky. Jeme mnoho. Pribúda nám tučných l’udí. Tuk je tkanivom staroby." ČÁRSKY, Konštantín. Správna výživa upevňuje zdravie a predlžuje život. In Výživa a zdravie, 1960, roč. 5, č. 9, s. 195-196.

57 ČÁRSKY, Konštantín. Aj mnoho dobrého škodí. In Výživa a zdravie, 1972, roč. 17, č. 12, s. 265-266.

58 ČÁRSKY 1960, s. 195. 
predsa zaváži, lebo za vojny, pri nedobrovol'nej striedmosti sa vyskytovali podstatne zriedkavejšie. Pribúda nám aj zvápenatenia tepní. I ked' je to choroba staroby, súvisí s výživou. Je častejšie u l'udí, ktorí jedia opulentne a ktorí konzumujú mnoho živočíšnych tukov. Jeme vel'a konzerv, zabúdame na význam surovej stravy, v podobe ovocia, zeleniny, šalátov a jedál čerstvo pripravených. ${ }^{59}$ Čársky patril medzi lekárov, ktorí propagovali nový životný štýl, dôležitost' konzumácie ovocia, zeleniny, zdravé jedlá a pohyb. Nový trend životosprávy sa začal čoraz viac uplatňovat’ aj na Slovensku.

Vo svojich prácach sa dotkol aj problematiky alkoholizmu. ${ }^{60}$ Podobne ako v predchádzajúcom období počet osôb závislých na alkohole predstavoval jeden zo závažných problémov v zdravotníctve. Napriek prijatým legislatívnym opatreniam a novým liečebným a preventívnym metódam výsledky neboli povzbudzujúce. Jeho prístup k riešeniu tohto problému bol radikálny. „Neodporúčam pit' akýkol'vek alkohol, ani pivo, sústavne, pravidelne. Odsudzujem rozšírený zvyk pit' pivo spolu s destilátmi. Neradím pit'víno alebo destiláty, ked’sme sami, zásadne nie v práci a na pracovisku. Páči sa mi zásada môjho nebohého učitela. Radil siahnut’ po kvalitnom alkohole výlučne po západe slnka, večer, po skončenej práci, na osvieženie a preladenie. [...] Pre alkoholizmus trpí nielen ním postihnutý jednotlivec, ale aj jeho užšie-širšie prostredie, rodina, pracovisko, spoločnost'. Azda je zbytočné spomínat' u alkoholikov časté rodinné rozvraty, zanedbanú výchovu detí, lúpeže, násilia, dopravné zmrzačenia. [...] Radíme, aby sa stal abstinentom ten, kto je slaboch, kto sa nevie ovládat', nevie pobadat', kedy má dost', nevie si dat'rozkaz „prestat'“ a aj ho splnit'. Mládeži alkohol mimoriadne škodí, nie iba pre lahkost' návyku, ale aj zdravotne. Jej prospieva dôsledná, uvedomelá výchova k zdržanlivosti. Spoločnost'si má túto úlohu uvedomit' a ciel'avedome ju plnit."'61

Ako lekár organizoval šport. Tvrdil, že čo sa nehýbe, zakrpatie. ${ }^{62}$ Mal obrovskú radost', ked' k športu pritiahol stovky mladých l'udí, pri ktorom získavali zdatnost', húževnatost', vytrvalost'. Bol horolezec, videl svet z mnohých tatranských štítov. Lyžoval a podmanila si ho aj kanoistika. Okrem ročného predsedovania v horolezeckom zväze po vojne „šéfoval“ takmer tridsat’ rokov našej kanoistike. ${ }^{63}$ Sám sa jej aktívne venoval. Rád chodil do prírody aj na polovačky, ozajstné polovníctvo spojené s ochranou zveriny považoval za ušlachtilý šport.

Profesor Čársky v oblasti zdravovedy publikoval stovky článkov a zastával názor, že zdraví sme vtedy, ked' sme schopní telesne a duševne odolávat' chorobám. Tvrdil, že nielen lieky, ale najmä

59 ČÁRSKY 1960, s. 195-196.

60 „Jedným - až tisícročia pretrvávajúcim zlozvykom l'udského plemena - je nemierne pitie alkoholu. [...] Pije sa všade, aj u nás, škoda, že pričasto nerozumne. Príčin bude viacero. Zaváži l'ahký prístup k alkoholu a dostatok prostriedkov, najmä u rozumove nevyspelých, nezrelých l'udí zadovážit' si ho. Medzi príčinami prídu do úvahy aj všeobecne dobré zárobkové možnosti. Zlozvyk donedávna vlastnost' mužov, sa ujíma aj u žien, žial', i u chlapcov a dievčat. V pití alkoholu zaujímame v svetovom meradle popredné miesto." ČÁRSKY, Konštantín. 0 tých, čo prídu po nás. In Výživa a zdravie, 1973, roč. 18, č. 12, s. 268.

61 ČÁRSKY, Konštantín. 0 tých, čo prídu po nás. In Výživa a zdravie, 1973, roč. 18, č. 12, s. 269.

62 „Relaxácii sa máme venovat’ denne i ked’ si nahovárame, že pre ňu niet času, ani vhodných podmienok. Životné tempo nás núti $k$ aktivite, $k$ vypätému plneniu nezbytných úloh. No predsa si máme nájst' hodinku pre uvol'nenie mysle a osvieženie tela $v$ intenciách takzvaného aktívneho odpočinku. Hodí sa preto prechádzka, v lete kúpanie, $v$ zime korčulovanie, lyžovanie, sánkovanie. Máme čarokrásnu prírodu. Krajšiu ako krčmy a kaviarne. [...] V prospech svojho zdravia sa musíme mnohému naučit' a zlozvykom odučit' Z vecí najprospešnejších je rozumná životospráva. Jej podstatnou súčastou je turistika." ČÁRSKY, Konštantín. Turistika a zdravie. In Výźiva a zdravie, 1964, roč. 9, č. 5, s. 98.

63 ZERER, Anton. Zapálený zlatokop zdravia. (Čársky, Konštantín). K osemdesiatke profesora Konštantína Čárskeho.) In Pravda, roč. 60, č. 80 (4. 4. 1979), s. 8. 
celková zmena stravovacích návykov a zdravý životný štýl je cestou k úspešnému zdolávaniu chorôb. ${ }^{64}$ Napriek všetkým dosiahnutým úspechom zostával až do smrti skromným človekom. Prvú chirurgickú kliniku v Bratislave viedol 29 rokov. Do dôchodku odišiel ako 72-ročný. Zomrel 23. mája 1987 vo veku 88 rokov.

\section{Záver}

Čo bolo charakteristické pre tieto dve osobnosti? V profesionálnej sfére dosiahli mimoriadne úspechy, svojím vkladom prekročili rámec československej chirurgie. Pochádzali z rozdielnych spoločenských pomerov. S. Kostlivý vyrastal v intelektuálnej rodine, ktorá patrila k vyššej strednej vrstve. Bol vol'nomyšlienkar, vynikal eleganciou, jemným spoločenským a empatickým správaním, bol profesionál za každých okolností. V jeho osobe sa skíbila vysoká odbornost' s manuálnou zručnostou chirurga. Ako chirurg, ktorý dennodenne čelil stresu, dokázal sa za každých okolností ovládat'. Pri operácii nikdy nezvyšoval hlas a neznervózňoval ostatných. Jeho najtvrdšia nadávka bola „Vy Indiáne!“ Ak o niekom zapochyboval, odzneli vzácne slová vrcholného odsúdenia. „Mám obavy, že X.Y. nie je charakter.“65 Profesor Kostlivý sa výrazne zapísal do dejín slovenskej chirurgie. Na Slovensku pôsobil dvadsat'dva rokov ako prednosta najvýznamnejšieho chirurgického pracoviska, I. chirurgickej kliniky Lekárskej fakulty UK.

K. Čársky sa narodil v sedliackej rodine, kde materiálne pomery neboli najlepšie. Bez finančnej pomoci brata - lekára, ktorý mu bol vzorom, len t’ažko mohol pomýšlat' na d'alšie štúdium. Nenaplnil očakávanie hlboko veriacej matky, aby sa stal kňazom. Jeho túžbou bolo pomáhat' pri záchrane l'udských životov, prinavracat’ zdravie a zmierňovat' l'udské utrpenie, čomu zasvätil celý svoj profesionálny život. Obidvaja profesori sa vyznačovali silným charakterom, zmyslom pre spravodlivost', mali vnútornú integritu a vášeň pre chirurgiu. Nakoniec sa stali aj príbuznými. Čársky sa oženil s Kostlivého dcérou. Okrem morálnych a profesionálnych kvalít vlastnili zriedkavý dar, nesmierne dôležitý pre najlepších manažérov - schopnost' vytiahnut' z tých druhých to najlepšie, čo v nich je. Ich žiaci a spolupracovníci využívali talenty, ktoré im boli dané, a na ich výsledkoch mohla budovat' nasledujúca generácia a postúpit’ na ceste za poznaním o krok vyššie.

64 SLOBODOVÁ, Elena - KLIMO, František. Sto rokov od narodenia prof. MUDr. Konštantína Čárskeho. In Slovenský lekár, 1999, roč. 9. (23), č. 10-11, s. 476.

65 ČÁRSKY 1947, s. 639.

Cituj:

FALISOVÁ Anna - OZOROVSKÝ Vojtech: Stanislav Kostlivý a Konštantín Čársky - elity slovenskej chirurgie. In Forum Historiae, 2018, r. 12, č. 1, s. 99-113. ISSN 1337-6861.

$\cdots$

PhDr. Anna Falisová, CSc.

Oddelenie dejín vedy a techniky

Historický ústav SAV,

P. O. Box 198,

Klemensova 19,

81499 Bratislava

histfali@savba.sk doc. MUDr. Vojtech Ozorovský CSc.

Univerzita Komenského v Bratislave UK

Lekárska fakulta

Ústav sociálneho lekárstva a lekárskej etiky

Sasinkova 2

81372 Bratislava

vojtech.ozorovsky@fmed.uniba.sk 